\title{
Venture Capital Sector in Pakistan: Ratio Analysis Approach for Financial Performance Assessment
}

\author{
Muhammad Farhan, Ali Raza, Abdul Jabbar Khan, Muhammad Akram* \\ Hailey College of Commerce, University of the Punjab, Lahore - Pakistan \\ *makram.hcc.pu.edu.pk@gmail.com
}

\begin{abstract}
The purpose of study is to rank the venture capital companies operating in Pakistan during the period of 2006-2009 on the base of their financial performance. Ratio analysis technique was used to rank the venture capital companies using profitability / efficiency ratios and total assets as proxies of financial performance. This study concludes that TRG Pakistan Limited is at first in ranking on the bases of return on assets (ROA), return on equity (ROE), and total assets, and at second on the base of earnings per share (EPS). AMZ Ventures Limited is at first on the base of earnings per share (EPS), at second in ranking on the bases of return on assets (ROA), return on equity (ROE), and total assets. TMT Ventures Limited is third on the bases of all ratios, and total assets. This is the first attempt that was made with an objective to facilitate the students, investors and management of company with useful information regarding financial performance of all venture capital companies operating in Pakistan.
\end{abstract}

\section{Key words: Venture capital, financial Performance, ranking, financial ratios, and Pakistan}

\section{Introduction}

Financial system is a key component of economic development in any country and it facilitates for funds mobilization to cover the financial requirements. Efficient and well stable financial system expresses good and efficient resources allocation and provides base for rising up the organizational financial performance. Venture capital companies, as peripheral of financial system and as a component of nonbanking finance companies (NBFCs), act as stakeholder for economy development. Venture capital companies are also playing a vital role in the financial sector of Pakistan. Currently, three venture capital companies are operating in Pakistan named as: AMZ ventures limited; TMT ventures limited; and TRG Pakistan limited. Moreover, all these companies are registered with the Securities and Exchange Commission of Pakistan (SECP). Venture capital is a one type of equity investment, invested privately. Jeng and Wells (2000) reported that when individual investors make investment privately in public and private companies then this type of investment is recognized as private sector investment.

Figure 1: The Ways that Firm Receive Venture Capital

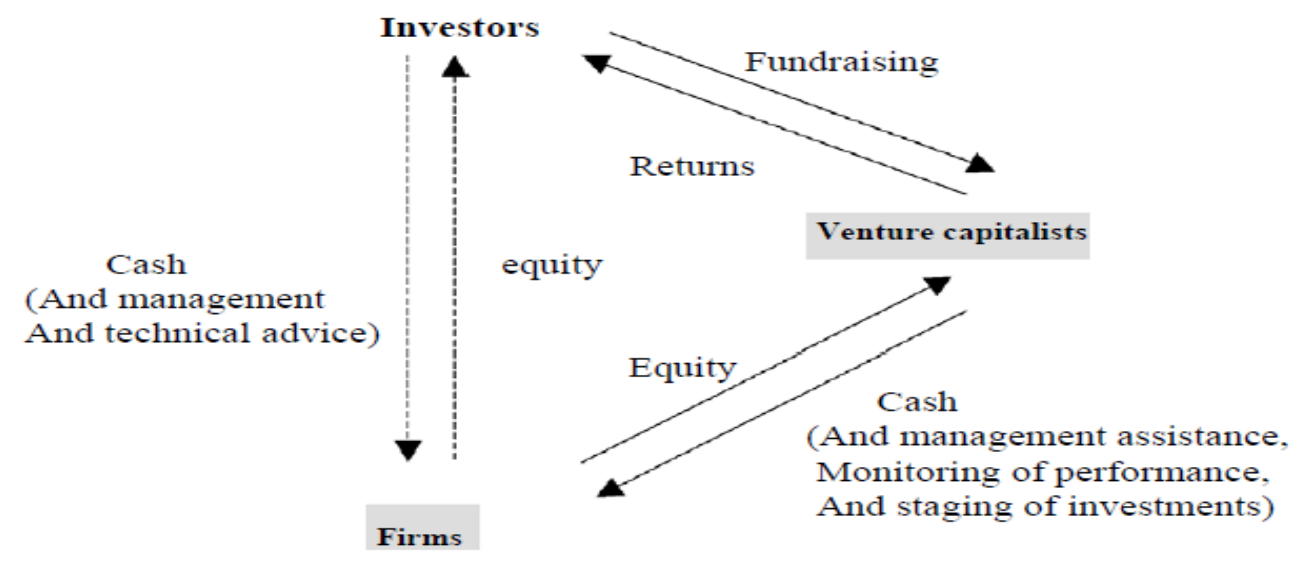

Figure 1 shows the capital flows of the venture capital companies. In the scenario of Pakistan, companies are allowed to whether invest from its own capital or raise capital from investors or other financial institutions. For example, TMT ventures capital company has total Rs. 250 million to invest from which Rs. 50 million was its' own capital, Rs. 75 million was invested by Pak-Kuwait investment company and remaining amount was financed from different financial institutions. The purpose of study was to rank the venture capital operating in Pakistan during the period of 2006-2009. Ratio analysis technique was 
used to rank the venture capital companies on the base of their financial performance. This was the first attempt made by the researcher to fill gap because no prior study was conducted in Pakistan related to the measure of financial performance of venture capital companies. This study will also serve as a benchmark and will provide help to the students, investors and prospective researchers while measuring the financial performance of venture capital companies as well as other financial institutions. This study is organized as: Section 1 explains the introduction; literature review is described in section 2; section 3 contains the data and methodology of this study; section 4 reveals the comparison and results; and conclusion is reported in section 5 .

\section{Literature Review}

Size of institution is affected by operating efficiency. It is determined through total assets of institutions. Tarawneh (2006) used total assets as a proxy of institution size. Spathis et al., (2001) \&; Koasmidou, (2008) found a negative relation between institution size and profitability. Ramlall (2009); Pilloff and Rhoades (2002); Molyneux and Seth (1998); Sufian (2009) found a positive relationship between institution size and profitability. They also examined the institution size dependence upon economies of scale and reported that larger institutions are more profitable than smaller institutions. Fukuyama (1996) concluded that size of bank is not important in Japanese banking sector to perform efficiently. Athanasoglou et al., (2008) claimed that capital is beneficial for institution size and portfolio composition. It has highly significant impact on profitability and gives power to fabricate strapping position in market whereas; a negative relation is reflected by capital maintenance problem with profitability (Naceur and Goaied, 2002). Berger and Humphrey (1997); Miller and No (1996) found that larger and high profitable institutions have high total earnings than smaller and less profitable institutions. Profitability shows the efficiency and effectiveness that how management of company is using resources to earn high profit in present and future to increase in the owners' wealth, earning per share etc. It can be determined through return on assets (ROA), return on equity (ROE), before tax profit (BTP), operative profit to total income etc. Avkiran (1995) reported that the coordination of financial ratios and measures, performance against budget, and many other techniques had been used in order to measure the financial performance of financial institutions. In current study, ratio analysis technique was used to rank the venture capital companies on the base of their financial performance. Profitability / efficiency ratios and total assets were used as proxies of financial performance. Moreover, all the selected ratios are recommended by State Bank of Pakistan (SBP). In the next section, data and methodology is explained.

\section{Data and Methodology}

This study was conducted in order to accomplish the above discussed objectives. Securities and Exchange Commission of Pakistan (SECP), State Bank of Pakistan and financial sector analyses report of period 2006-2009 were the main sources for data collection. Three venture capital companies are operating in Pakistan and all selected for analysis. To analyze and compare the financial performance of venture capital companies, financial ratios were used as a tool on the base of different studies such as (Alam et al., 2011); (Raza et al., 2011); (Alam et al., 2011); (Ahmad et al., 2011); (Alam et al., 2011). Names of financial indicators were;

- Profitability / Efficiency Ratio

- Return on Owners' Equity (ROE)

- Return on Assets (ROA)

- Earning per Shares (EPS)

- Total Assets used as proxy of institution size.

\section{Results and Discussion}

Table 1: Return on Equity (ROE)

\begin{tabular}{lccccc}
\hline \multirow{2}{*}{ Venture capitals } & \multicolumn{5}{c}{ Values in percentages (\%) } \\
& $\mathbf{2 0 0 6}$ & $\mathbf{2 0 0 7}$ & $\mathbf{2 0 0 8}$ & $\mathbf{2 0 0 9}$ & Average \\
\hline AMZ Ventures Limited & -6.57 & -6.32 & -10.94 & -5.16 & -7.25 \\
TMT Ventures Limited & 66.57 & -117.75 & -3.24 & -551.05 & -149.75 \\
TRG Pakistan Limited & -6.26 & -1.43 & -1.43 & 30.54 & 21.42 \\
\hline
\end{tabular}




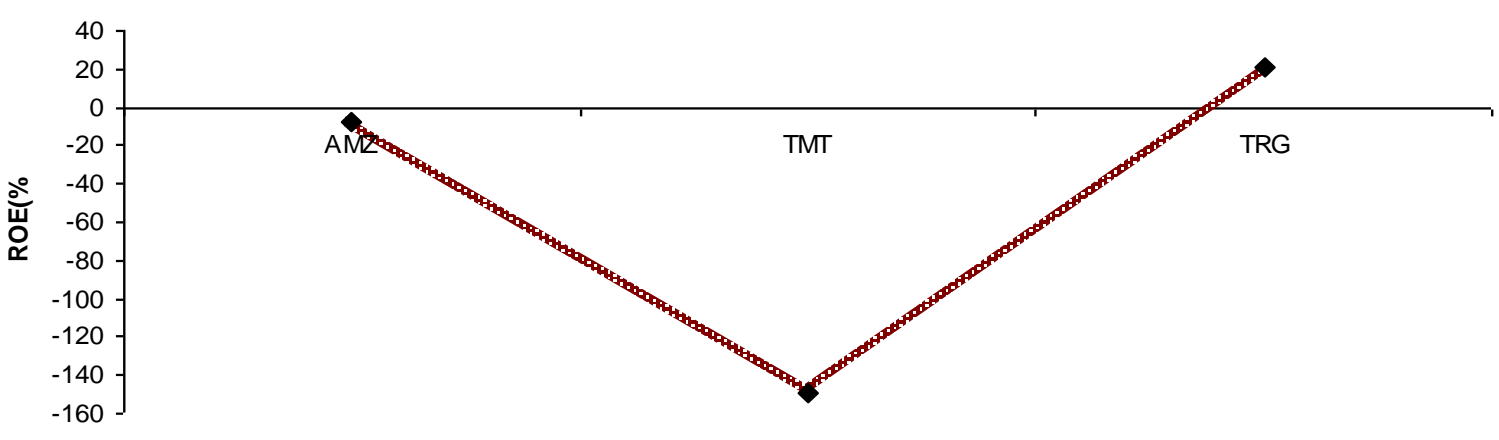

Name of ventures capital

Table $01 \&$ figure 02 demonstrates the data of venture capital companies regarding return on equity during the period of 2006-2009 along with average of four years. This ratio is calculated as a percentage of after tax profit to total equity. This ratio directly and indirectly shows the efficiency of management related to the process of revenue generation after utilization of owners' equity, which means that how effectively and efficiently the owners' equity is being used to earn profit. This four year ROE trend will help investors to analyze the profitability trend of a company. Generally, it is presumed that higher the ROE, better the profitability as well as financial performance of company. On the base of table and figure it can be concluded that TRG Pakistan limited has the highest positive average ROE ratio (21.42), and TMT Venture limited has the highest negative average ROE ratio (-149.75). Therefore, it is suggested for those investors that take into consideration the ROE ratio while taking investment decision to make investment in TRG Pakistan limited due to its high ROE ratio.

Table 2.Return on Assets (ROA)

\begin{tabular}{lllllc}
\hline \multirow{2}{*}{ Venture capitals } & \multicolumn{5}{c}{ Values in percentage (\%) } \\
& $\mathbf{2 0 0 6}$ & $\mathbf{2 0 0 7}$ & $\mathbf{2 0 0 8}$ & $\mathbf{2 0 0 9}$ & Average \\
\hline AMZ Ventures Limited & -4.06 & -3.67 & -5.72 & -2.46 & -3.98 \\
TMT Ventures Limited & 61.11 & -85.51 & -1.19 & -71.54 & -24.28 \\
TRG Pakistan Limited & -3.71 & -1.42 & -1.42 & 30.06 & 5.88 \\
\hline
\end{tabular}

Figure 03- Graphical Representation of average return on assets (ROA)

Average Return on Assets (ROA)

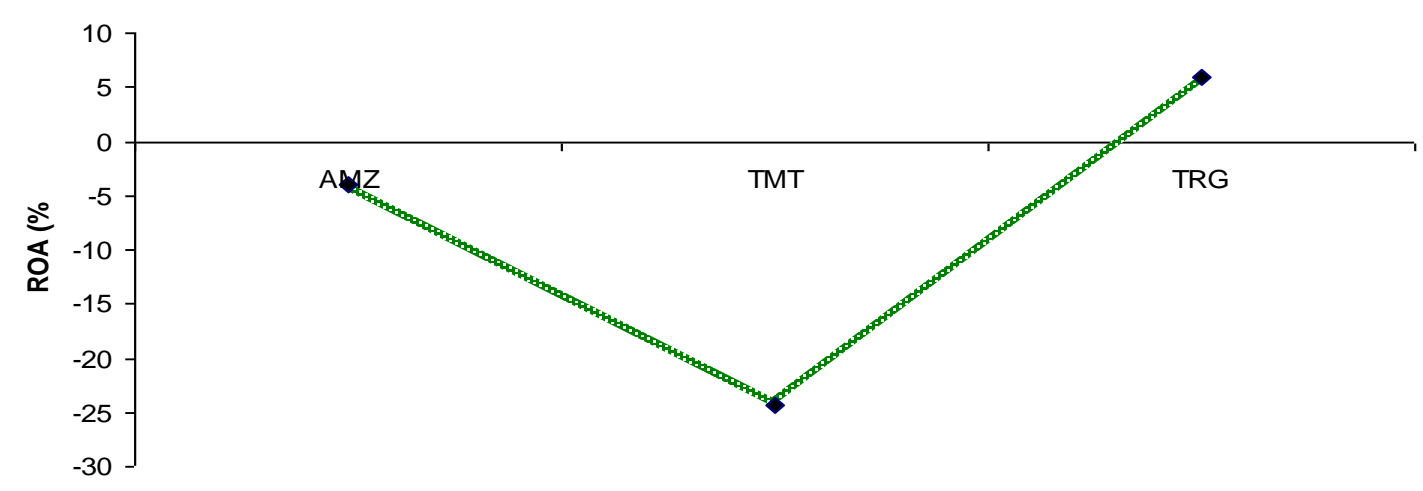

Name of ventures capital

Table 02 \& figure 03 shows the data of venture capital companies regarding return on assets during the period of 2006-2009 along with average of four years. This ratio is calculated as a percentage of after tax profit to total assets. This ratio also directly and indirectly shows the ability of management related to the process of revenue generation after utilization of assets that means that how effectively and efficiently the 
total assets are being used to earn profit. General assumption is that higher the ROA, better the profitability of company. On the base of table and figure it can be concluded that TRG Pakistan limited has the highest positive average ROA ratio (5.88), and TMT Venture limited has the highest negative average ROE ratio (-24.28). Therefore, it is suggested for those investors that take into consideration the ROA ratio while taking investment decision to make investment in TRG Pakistan limited due to its high ROA ratio.

Table 3: Earning per Shares (EPS)

\begin{tabular}{lccccc}
\hline \multirow{2}{*}{ Venture capitals } & \multicolumn{3}{c}{ Earning per Shares (EPS) Rs. } \\
& $\mathbf{2 0 0 6}$ & $\mathbf{2 0 0 7}$ & $\mathbf{2 0 0 8}$ & $\mathbf{2 0 0 9}$ & Average \\
\hline AMZ Ventures Limited & 0.60 & -0.55 & -0.85 & -0.38 & -0.59 \\
TMT Ventures Limited & 9.82 & -9.98 & -9.80 & -2.34 & -2.08 \\
TRG Pakistan Limited & -0.23 & -0.09 & -0.09 & -1.99 & -0.60 \\
\hline
\end{tabular}

Figure 04: Graphical Representation of average earning per share (EPS)

Average Earning Per Share (EPS)

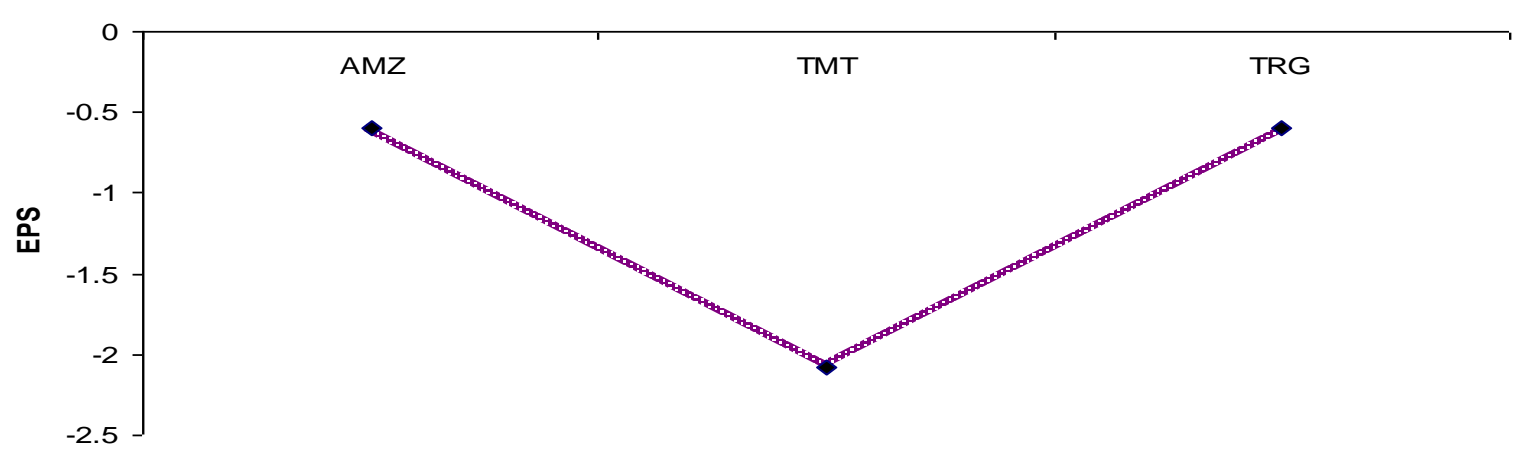

Name of ventures capital

Table 03 \& figure 04 clarifies the data of venture capital companies regarding earnings per share during the period of 2006-2009 along with average of four years. This ratio describes that how much a shareholder earns on his outstanding shares in every year. In other words, it shows that how much a company earns against each share. All investors give ample importance to this ratio while analyzing company's performance before making an investment. Generally, it is alleged that higher the EPS, better the profitability and efficiency of a company. This is calculated as a percentage of after tax profit to total outstanding shares. On the base of table and figure it can be concluded that AMZ venture limited has the lowest negative average EPS ratio (-0.59), and TMT Venture limited has the highest negative average EPS ratio $(-2.08)$. Therefore, it is suggested that to make investments in all three firms are very risky due to their negative EPS.

Table 4: Total Assets of Venture Capital Companies

\begin{tabular}{lllllll}
\hline \multirow{2}{*}{ Venture capitals } & \multicolumn{5}{c}{ ( Values in Rs. 000 ) } \\
& \multicolumn{1}{c}{$\mathbf{2 0 0 6}$} & \multicolumn{1}{c}{$\mathbf{2 0 0 7}$} & $\mathbf{2 0 0 8}$ & \multicolumn{1}{c}{$\mathbf{2 0 0 9}$} & \multicolumn{1}{c}{ Growth Rate } & Average \\
\hline AMZ Ventures Limited & 445610 & 446393 & 446710 & 466524 & $106.70 \%$ & 451309.25 \\
TMT Ventures Limited & 24112 & 13999 & 12384 & 8827 & $36.61 \%$ & 14830.50 \\
TRG Pakistan Limited & 3661101 & 3595609 & 3595609 & 2549613 & $69.64 \%$ & 3350408 \\
\hline
\end{tabular}


Figure 05: Graphical Representation of average of Total Assets

\section{Average of Total Assets}

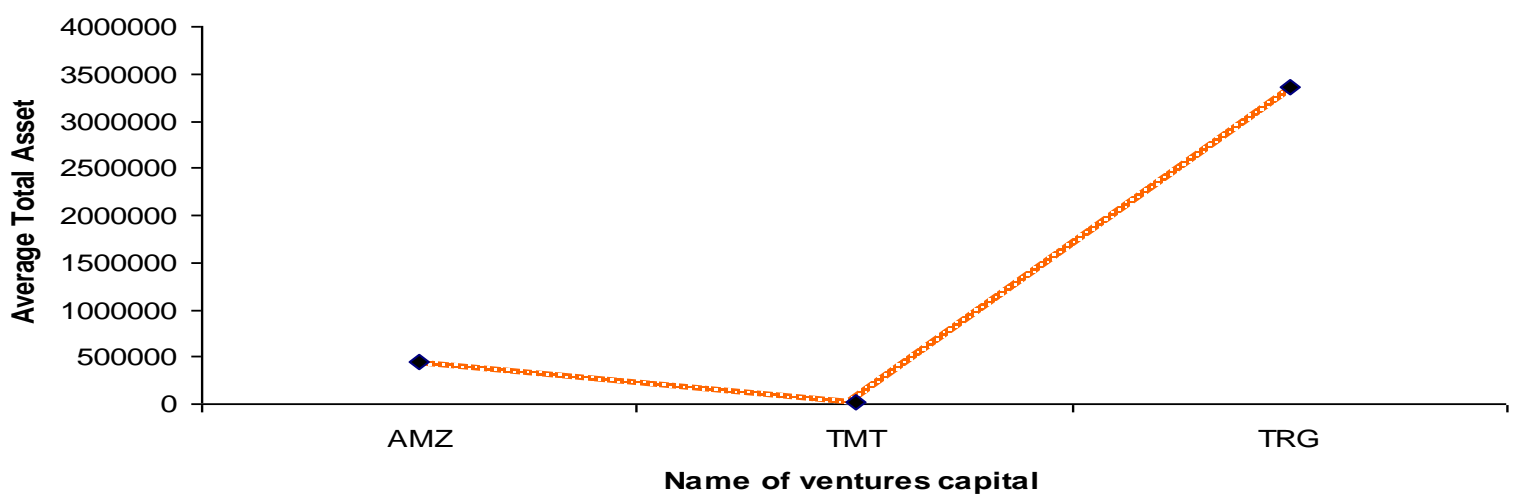

Table $04 \&$ figure 05 reveals the data of venture capital companies regarding total assets of venture capital companies during the period of 2006-2009 along with average of four years. Total assets show strengthens of a company and growth rate serves as a good indicator. This ratio was selected because Ramlall (2009); Pilloff and Rhoades (2002); Molyneux and Seth (1998); \& Sufian (2009) found a positive relationship between institution size and profitability. It is also recognized that most of the investors have high level of trust on the company. Therefore, they make investment in shape of capital or debt, and all the assets are financed through the amount of capital and debt. On the base of table and figure it can be concluded that AMZ ventures limited has the highest growth rate $(106.70 \%)$ and TMT ventures limited has the lowest growth rate (36.61\%). Whereas, TRG Pakistan limited has the highest average total assets (Rs.3350408), and TMT Venture limited has the lowest average capital ratio (Rs.14830.50).

Table 5: Ranking of Venture capital based on Financial Ratios and Measures

\begin{tabular}{lccc}
\hline \multirow{2}{*}{ Financial Ratios \& Measure } & AMZ & TMT & TRG \\
\hline Profitability / Efficiency Ratios & & & \\
1. Return on Equity (ROE) & 2 & 3 & 1 \\
2. Return on Assets (ROA) & 2 & 3 & 1 \\
3. Earnings per Share (EPS) & 1 & 3 & 2 \\
Financial Measure & & & \\
1. Total Assets & 2 & 3 & 1 \\
\hline
\end{tabular}

\section{Conclusion}

On the base of analyses and results of this study, it was concluded that TRG Pakistan Limited was at first, AMZ Ventures Limited was second and TMT Ventures Limited was third in ranking. This ranking was made in such a manner that TRG Pakistan Limited was at first position in all ratios except one ratio, AMZ Ventures Limited was at second position in all ratios except one and TMT Ventures Limited was at third position in all ratios. This was the first attempt made by the researcher to fill gap because no prior study was conducted in Pakistan related to the measure of financial performance of venture capital companies but this ranking is only and only for purely academic purpose. This study will also serve as a benchmark and will provide help to the students, investors and prospective researchers while measuring the financial performance of venture capital companies as well as other financial institutions. It is also recommended to investors that although these ratios are strong indicators of company's profitability and financial performance but do not fully rely on these ratios while analyzing a company's financial performance. Moreover, increase in the period of analysis may tend to further study. 


\section{References}

Aburime, U., T. (2009). Impact of political affiliation on bank profitability in Nigeria. African Journal of Accounting, Economics, Finance, and Banking Research, 4(4), 61-75.

Ahmad, H., K., Raza, A., Amjad, W. \& Akram, M. ( 2011). Financial performance of non banking finance companies in Pakistan. Interdisciplinary Journal of Contemporary Research in Business, 2(12), 732744.

Alam, H., M., Raza, A. \& Akram, M. (2011). A financial performance comparison of public vs private banks: the case of commercial banking sector of Pakistan. International Journal of Business and Social Science, 2(11), 56-64.

Alam, H., M., Raza, A. \& Akram, M. (2011). Financial performance of leasing sector: The case of pakistan. Interdisciplinary Journal of Contemporary Research in Business, 2(12), 339-345.

Alam, H., M., Raza, A., Farhan, M. \& Akram, M. (2011). Leasing industry in pakistan: a comparison of financial performance of leasing companies. International Journal of Business and Social Science, 2(10), 218-223.

Athanasoglou, P., P., Brissimis, S., N. \& Delis, M., D. (2008). Bank-specific, industry-specific and macroeconomic determinants of bank profitability. International Financial Markets Institutions \& Money, 18, 121-136.

Avkiran, N., K. (1995). Developing an instrument to measure customer service quality in branch banking. International Journal of Banks Merketing, 12(6), 10-18.

Berger, A. N. \& Humphrey, D. B. (1997). Efficiency of financial institutions: international survey and directions for future research. European Journal of Operational Research, 98, 175-212.

Fukuyama, H. (1996). Returns to Scale and Efficiency of Credit Associations in Japan: A Nonparametric Frontier Approach. Japan and the World Economy, 8, 259-77.

Jeng, L. A. \& Wells, P. H. C. (2000). The determinants of venture capital funding: evidence across countries. Journal of corporate finance, 6(3), 241-289

Koasmidou, K. (2008). The determinants of banks' profits in Greece during the period of EU financial integration. Managerial Finance, 34(3), 146-159.

Miller, S. M. and Noulas, A. G. (1996). The technical efficiency of large bank production. Journal of Banking and Finance, 20, 495-509.

Molyneux, P. \& Seth, R. (1998). Foreign banks, profits and commercial credit extension in the United States. Applied Financial Economics, 8, 533-539

Naceur, S., B. \& Goaied, M. (2002). The relationship between dividend policy, financial structure, profitability and firm value. Applied Financial Economics, 12, 843-849

Pilloff, S., J. \& Rhoades, S., A. (2002). Structure and Profitability in Banking Markets. Review of Industrial Organization, 20, 81-98.

Ramlall, I. (2009). Bank-Specific, Industry-Specific and Macroeconomic Determinants of Profitability in Taiwanese Banking System: Under Panel Data Estimation. International Research Journal of Finance and Economics, (34), 160-167.

Raza, A., Farhan, M. \& Akram, M. (2011). A Comparison of Financial Performance in Investment Banking Sector in Pakistan. International Journal of Business and Social Science, 2(9), 72-81.

Spathis, C., Koasmidou, K. \& Doumpos, M. (2002). Assessing Profitability Factors in the Greek Banking System: A multicriteria methodology. International Transactions in Operational Research, 9, 517530.

Sufian, F. (2009). Determinants of bank efficiency during unstable macroeconomic environment: Empirical evidence from Malaysia. Research in International Business and Finance, 23, 54-77.

Tarawneh, M. (2006). A comparison of financial performance in the banking sector: Some Evidence from Omani Commercial Banks. International Research Journal of Finance and Economics, (3), 101-112. 